\title{
Development and Characterization of Bioactive Polypropylene Films for Food Packaging Applications
}

\author{
Adrian Krzysztof Antosik*(1), Urszula Kowalska, Magdalena Stobińska, Paulina Dzięcioł, Magdalena Pieczykolan, \\ Katarzyna Kozłowska and Artur Bartkowiak
}

check for

updates

Citation: Antosik, A.K.; Kowalska, U.; Stobińska, M.; Dziẹcioł, P.; Pieczykolan, M.; Kozłowska, K.; Bartkowiak, A. Development and Characterization of Bioactive Polypropylene Films for Food Packaging Applications. Polymers 2021, 13, 3478. https://doi.org/ $10.3390 /$ polym 13203478

Academic Editors: Alexey Iordanskii and Marina Patricia Arrieta Dillon

Received: 19 July 2021

Accepted: 6 October 2021

Published: 11 October 2021

Publisher's Note: MDPI stays neutral with regard to jurisdictional claims in published maps and institutional affiliations.

Copyright: (c) 2021 by the authors. Licensee MDPI, Basel, Switzerland. This article is an open access article distributed under the terms and conditions of the Creative Commons Attribution (CC BY) license (https:// creativecommons.org/licenses/by/ $4.0 /)$.
Center of Bioimmobilisation and Innovative Packaging Materials, Faculty of Food Sciences and Fisheries, West Pomeranian University of Technology, Szczecin, Klemensa Janickiego 35, 71-270 Szczecin, Poland; urszula.kowalska@zut.edu.pl (U.K.); mstobinska@zut.edu.pl (M.S.); paulina.dzieciol@zut.edu.pl (P.D.); magdalena.pieczykolan@zut.edu.pl (M.P.); katarzyna.kozlowska@zut.edu.pl (K.K.); artur.bartkowiak@zut.edu.pl (A.B.)

* Correspondence: adriankrzysztofantosik@gmail.com

\begin{abstract}
Bioactive polypropylene (PP) films with active agents) presence for food packaging application have been prepared and characterized. The novel modified PP films were obtained via $\mathrm{PP} /$ additives systems regranulation and cast extrusion. The influence of two types of plasticizers (natural agents as well as commercial synthetic product) and bioactive additives on final features, e.g., mechanical properties, was evaluated. Moreover, the biocidal activity of the films was determined. Due to their functional properties, they are developed as additives to packaging plastic materials such as polyolefins. The study results presented in our work may indirectly contribute to environmental protection by reducing food waste. The aim of the work was to obtain innovative, functional packaging materials with an ability to prolong the shelf life of food products. The best antimicrobial properties were observed for the sample based on $5 \mathrm{wt}$ \% oregano oil (OO) and $5 \mathrm{wt} . \%$ cedar oil (OC) in PP matrix. A microbial test revealed that the system causes total reduction in the following microorganisms: B. subtilis, E. coli, S. aureus, P. putida, C. albicans, A. alternata, F. oxysporum.
\end{abstract}

Keywords: bioactive substances; polyolefin-based films; packaging; processing technologies

\section{Introduction}

Recently, consumers have become more aware of health issues and eat more nutritious food. They consume lot of fresh fruits, vegetables and they are willing to pay a higher price for better quality products. Thus, the demand for local and domestic fruits has greatly increased throughout all seasons. There are many obstacles to the delivery of fresh products, e.g., limition of the ability to deliver fresh, high quality products such as the seasonality of crops and the need to transport off-season products from various geographic areas. Long-distance transport can affect, e.g., by physical injury, the appearance of microbial flora, water loss, and changes in storage temperature. In order to extend freshness, more emphasis is placed on packaging methods. Studies presented in the literature has shown that proper packaging can extend the shelf life of products by up to $100 \%$ of the storage time. They constitute a physical barrier between the external environment and the packed products. From a technological point of view, they form a separate part of the space that protects the product, e.g., food, from damage or faster deterioration. The modifications of the film with bioactive agents presented in the paper allow us to extend the life of the food product by stopping the development of microorganisms in its packaging [1-4].

In addition to EU standard requirements for the materials used in packaging focus on usage of biodegradable or easily recyclable materials. The packaging materials should be suitable for contact with food products. For this reason, products such as fruit and vegetables are often packaged in monopolymer-based heat sealed bags or stretch wrapped 
trays. This lead to extend the freshness of the products, formation of independent microclimate in the space separated by the packaging. Therefore, to sustain the product freshness, more manufacturers add bioactive agents into packaging materials. It is common practice to cover the inner side of the film with a layer containing these agents (such as varnish) or to introduce them into the inserts, while it is rare to introduce bioactive agents in situ to the packaging film. In this way, the active compounds contained in the packages are released into the environment, separated by the package and limits microorganism growth on the surface of fruit and vegetables. Bioactive agents are more accepted additives than commercial antimicrobial substances such as antibiotics which have similar activity [5-10].

Tomatoes belong to the most popular group of crop plants. They contain a great deal of vitamins (e.g., K, PP and B group), macro- and microelements necessary for the proper functioning of human body. Due to their valuable properties, the stage of storing tomatoes is very important, because their speed of ripening can be manipulated by applying certain conditions. According to the literature, too low storage temperature (blow $5^{\circ} \mathrm{C}$ ) may lead to a loss of sensory quality, or cell or tissue damage to the tomatoes. The most optimal storage conditions for harvested tomatoes are temperature range between 18 and $21^{\circ} \mathrm{C}$, but the usual cold chain is ca. $12{ }^{\circ} \mathrm{C}$. Depending on the storage conditions by consumers, tomatoes may have different freshness times. Tomatoes stored at higher temperatures, e.g., at room temperature, lose their freshness earlier than at lower temperatures, because degradation of tomato tissues are much faster. To extend its shelf life, both at high and low temperatures, commercial polypropylene (PP) or polyethylene (PE) are modified with different natural additives with antimicrobial properties and they are approved for food as safe packaging materials [11-14].

In our study, we examined the antimicrobial and antifungal activity of essential oils (EO). They form a diverse group of chemical agents that include, e.g., aldehydes, alcohols, esters, and phenols. Essential oils with potential antimicrobial properties were selected from the literature. The tested substance was oregano oil. This oil exhibits antioxidant, antifungal, anti-inflammatory properties, and is approved for food contact. Rosemary extract has been used in food preservation to prevent microbial contamination and oxidation. As a preservative, it replaces synthetic antioxidants in foods. Rosemary extract is commonly used in medicine. In our study, we also used methylparaben as a substance to enhance antibacterial properties. Parabens are applied as anti-microbials in foods, pharmaceutics and cosmetics. In the European Union, methylparaben is limited in application. In the United States, this substance is declared by the FDA to be "generally recognized as safe" (GRAS). Green tea containing, e.g., catechins, are polyphenolic compounds. Green tea extracts possess anti-tumor, anti-inflammatory, anti-oxidative, anti-microbial, anticarcinogenic properties [15-20].

Polypropylene (PP) is one of the two most commonly used plastics, next to polyethylene. PP is characterized by very good chemical resistance, high thermal expansion, good weldability, high tensile strength, and an operating temperature from $-20^{\circ} \mathrm{C}$ to $+100{ }^{\circ} \mathrm{C}$ (as a product). It is aseptic and physiologically inert, and does not absorb moisture. The tests showed greater stiffness and hardness than PE. PP was selected for the tests by its properties described in the article and for modifications with active agents and plasticizers. PP is a stable material and widely used in packaging as well as being easy to recycle. Currently, PP is the one of the most frequently chosen plastics for the foil production. The stability of the processing (both in regranulation and in cast extrusion) makes it a desirable polymer matrix for modification [21-24].

This work uses a bioactive product as an additive for modified PP films used in the packaging industry. In addition, plasticizers will be added, for supporting a migration of bioactive agents to an environment. The objectives of this study were to develop an active PP film containing bioactive agents by an extrusion (mixing of PP and additives), cast film extrusion method and to characterize the films physical properties. This study also evaluated the antimicrobial and biostatic properties of the developed films. Finally, this investigation examined the influence of selected films on the storage stability of tomatoes 
at simulated conditions. Similar research has already been carried out, where films with antimicrobial properties based on PLA with oregano oil were obtained [25]. We expected a similar or better effect after introducing oregano oil with the plasticizer to the PP matrix.

\section{Experimental}

2.1. Materials

Commercial polypropylene was used (acronym: HP515M, Melt Flow Rate $\left(230^{\circ} \mathrm{C} /\right.$ $2.16 \mathrm{~kg}$ ): $9.0 \mathrm{~g} / 10 \mathrm{~min}$, Density: $0.90 \mathrm{~g} / \mathrm{cm}^{3}$, Vicat Softening Temperature $\left.(\mathrm{A} / 50 \mathrm{~N}): 153^{\circ} \mathrm{C}\right)$, which was product of BasellOrlen (Poland). As plasticizers, Atmer 121 (A121), product of Croda (UK), and cedar oil (CO), isolated form pine nuts (Pinus sibricae), product of Ekamedica (Poland), were applied. Rosemary extract (RE), product of Exeller (Belgium), oregano oil (OO), product of Hepatica (Turkey), methylparaben (MP), product of Chmes (Vietnam), and green tea extract (GTE), product of Exeller (Poland), were used as bioactive agents.

\subsection{Preparation of PP-Based Films-Regranulation and Cast}

\subsubsection{Regranulation}

The regranulation process was performed using twin screw extruder (10 heating zones, Labtech Engineering, Thailand). PP pellets were extruded with plasticizers and various bioactive agents (as powders, pastes and liquids) in order to obtain uniformly blended pellets. The following during the tests were applied $170-190{ }^{\circ} \mathrm{C}$ and $170-185^{\circ} \mathrm{C}$ processing parameters for mono-modified systems and mix-modified systems, respectively (Table S1).

\subsubsection{Cast}

The final native and modified PP pellets were extruded through a flat die using Multilayer Chill-Roll Cast Film Extrusion Line Type LCR-300 Co-Ex (Labtech Engineering, Thailand) in a single-layer mode in order to obtain a films with a thickness of 50 to $150 \mu \mathrm{m}$. The following temperature profiles during the tests were as follows: $175-210^{\circ} \mathrm{C}, 175-195^{\circ} \mathrm{C}$ and $160-185^{\circ} \mathrm{C}$ temperature processing parameters for native PP, mono-modified pellets and mix-modified pellets, respectively (Table S2).

\subsubsection{Experimental Design}

The experiment was designed in the four stages (Figure S1). In the first stage, the influence of individual components on the properties of the obtained films was determined and individual correlations (two-component films) were investigated. The research confirmed the synergism between the bioactive agent and the plasticizer (the plasticizer facilitated the release of the bioactive agent, acting as a biocide by increasing the concentration of the released additives). Taking advantage of this, we attempted to increase the biocidal activity of the film while maintaining its processing and functional properties-stage 2 and 3 , obtaining three-component and multi-component films, respectively. In the last, fourth stage, the best films were selected and preliminary storage tests and weldability tests were carried out. The experimental design used single-factor designs for trials in the scheme of independent groups. The statistical analysis was based on ANOVA and was supported with statistical comparative analysis (Duncan).

\subsubsection{Selection of Representative Strains of Bacteria}

In microbiological experiments, four preselected bacterial strains, one yeast and four fungi strains were applied (the choice based on the most popular microflora occurring on surface of fresh vegetables and fruits). The microorganisms were purchased from a German Collection of Microorganisms (DSMZ): Bacillus subtilis DSM 1090, Pseudomonas putida DSM 6125 and also Staphylococcus aureus DSM 346 and Escherichia coli DSM 498, which are indicated in the antimicrobial standards ASTM E 2180-01 [26]. From Polish Collection of Microorganisms (PCM), Candida albicans PCM 2566. The fungi strains were from the Czech Collection of Microorganisms (CCM); Alternaria alternata CCM F-397, Fusarium oxysporum 
CCM F-545, Penicillium expansum CCM F-576 and Aspergillus brasiliensis CCM 8189 were obtained.

\subsubsection{Selection of Final Antimicrobial Substance}

Oregano oil, rosemary extract, methylparaben and green tea extract have been identified as the most promising antimicrobial substances according to the authors of [27-30]. The MIC (Minimal Inhibitory Concentration) tests were carried out, as the recommended method by EUCAST (European Committee on Antimicrobial Susceptibility Testing). The results confirmed the antimicrobial activity of these substances and the selection of the appropriate concentration are presented in the results.

\subsection{Methods}

\subsubsection{Mechanical Properties}

Mechanical tests were carried out on the Zwick/Roell Z 2.5 machine, Ulm Germany (2.5 kN head) according to ASTM D822-02. The samples were cut into strips of $15 \mathrm{~mm}$ in width and placed between clamps with $50 \mathrm{~mm}$ distance and elongated at tensile speed $100 \mathrm{~mm} / \mathrm{min}$. At least seven replicate samples were tested. The elongation at break, maximum tensile strength, Young's modulus with standard deviations were calculated with TestXpert II software.

Melt flow index (MFI) was carried out on the RB-M Plastometer machine, Rolbatch $\mathrm{GmbH}$, Germany, according to the standard tests carried out in accordance with the manufacturer's instructions according to the standard method A and according to ISO 1133 (load $1.26 \mathrm{~kg}$, temperature $230^{\circ} \mathrm{C}$ ).

\subsubsection{Thermal Characteristics}

Thermal characteristics were assessed by thermogravimetric analysis (TGA) using TA Instruments Inc. model 2950 TGA unit interfaced with the TA Instruments Thermal Analyst 2100 control unit. All samples, of about ca. $10 \mathrm{mg}$, were placed in the platinum pan and analyzed with air atmosphere at $60 \mathrm{ml} / \mathrm{min}$ during the thermo-analysis process. The temperature was ramped at $5{ }^{\circ} \mathrm{C} / \mathrm{min}$.

\subsubsection{Infrared Spectroscopy}

FTIR analysis was performed using the Nexus (Thermo-Nicolet, Waltham, MA, USA) technique equipped with ATR. For each sample. A total of 32 scans were taken from 4000 to $400 \mathrm{~cm}^{-1}$.

\subsubsection{Antimicrobial Properties}

The antimicrobial properties of PP films with active agents were evaluated according to ASTM E 2180-18 standard. Samples of extruded PP films of $3 \mathrm{~cm} \times 3 \mathrm{~cm}$ with active substances were prepared. The concentrations of the microorganism were standardized to $1.5 \times 10^{8} \mathrm{cfu} / \mathrm{mL}$ and suspended in $100 \mathrm{~mL}$ of $0.85 \% \mathrm{NaCl}$ with $0.3 \%$ agar. The final concentration of each strains was $1.5 \times 10^{6} \mathrm{cfu} / \mathrm{mL}$ in agar suspension. Inoculated agar $(1.0 \mathrm{~mL})$ was pipetted onto each square film sample and introduced into the sterile Petri dishes. All samples were incubated in climate chamber for $24 \mathrm{~h}$ (bacteria and yeast), $48 \mathrm{~h}$ (fungi) at $30{ }^{\circ} \mathrm{C}$ with relative humidity at $90 \%$. After incubation, the samples were introduced into the $100 \mathrm{~mL}$ of tryptic soy broth medium (TSB, Merck Germany) and serial dilutions of the initial inoculum were performed. Each dilution was spread into the agar medium and incubated for each strain's reference culture temperature. All measurements were performed in duplicate from each active films. The obtained results were presented as an average value with standard deviations of three replicates. Where relevant, the data were subjected to one-way analysis of variance using ANOVA test. 


\section{Results and Discussion}

As relatively high temperatures are applied in the PP thermo-processing (both regranulation and cast extrusion), which could cause an undesirable loss of the bio-additives quantity, adjusting them to the thermal resistance of the additives is necessary. In order to evaluate a potential excessive losses of bioactive agents, thermogravimetric analysis was carried out to determine their behavior at increased temperature (Figure 1). Both methylparaben as well as green tea extract showed higher thermal resistance compared to the essential oil and rosemary extract. In the case of $\mathrm{OO}$ and RE, a significant loss of mass occurred at a temperature of about $230-250{ }^{\circ} \mathrm{C}$, which is above the processing temperature described in the literature [31,32]. Due to high weight loss of the rosemary extract and oregano oil samples (100 and ca. $50 \%$ of the sample weight lost, respectively) at ca. $200{ }^{\circ} \mathrm{C}$, the processing temperature profiles were lowered for processed PP pellets modified with individual components in the range from 175 to $195^{\circ} \mathrm{C}$ on the end of line (Tables S1 and S2) in order to release as little as possible of bioactive agent (similar content to introduced amount into the premix) from the polymer matrix [23,25]. However, due to the production process (extrusion and cast extrusion), these bioactive agent (e.g., oregano oil) are trapped in the polymer bulk, migrate and evaporate from the surface of the pellet/film. Loss of additives form PP can be minimized to $15-25 \%$ via lowering the temperature profiles of the extrusion and increasing the cooling rate of extrudate $[25,33,34]$. The initial small weight loss each of analyzed active substance at ca. was probably ascribed to the moisture. The second step presented a significant mass loss. This loss may also be attributed to the volatilization/decomposition of bioactive compounds from the substances, e.g., for rosemary extract, possibly decomposition off phenolic diterpenes, such as carnosic acid and carnosol, as well as rosmarinic acid. For green tea extract, oregano oil and rosemary extract, the third step-small mass loss—can be related to inorganic compounds [23,25,31-34].

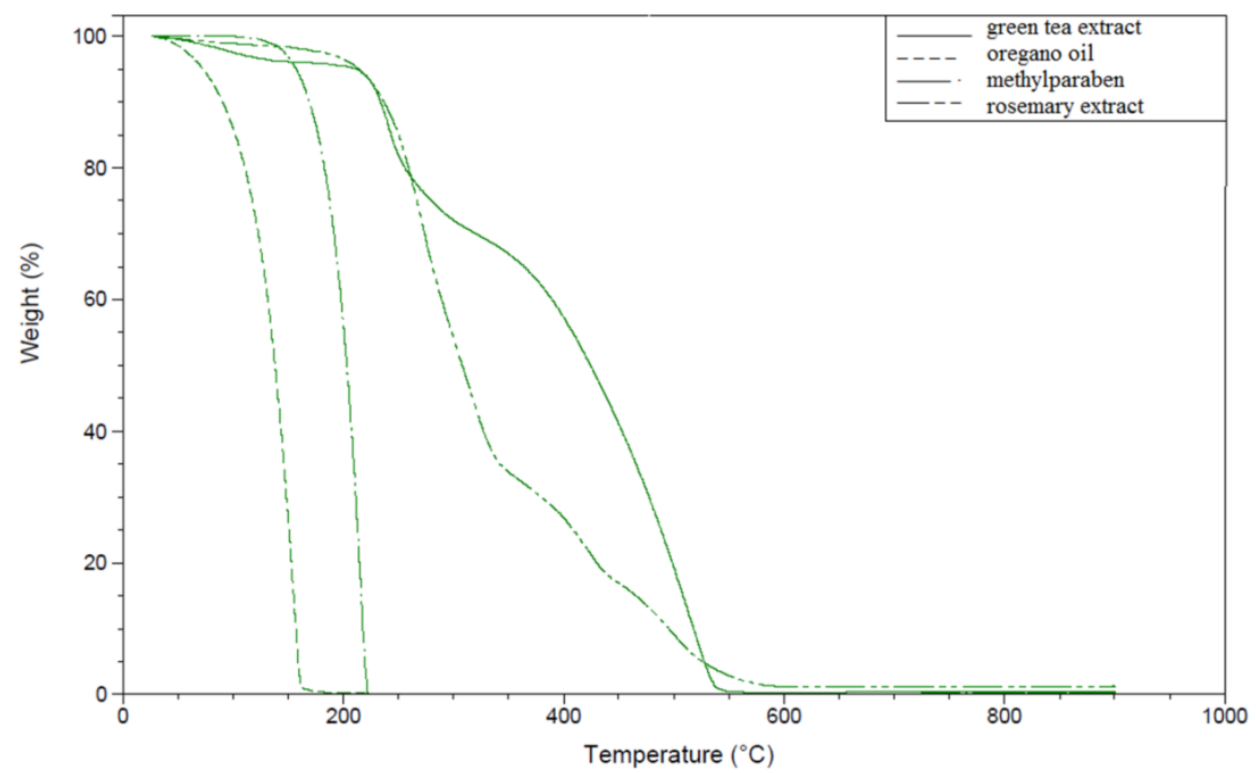

Figure 1. TG curves of selected active agents.

The influence of additives on the mechanical properties of PP films was determined. The bioactive properties of the obtained new films were checked on the basis of the obtained results. Premixes with two components were prepared to investigate their joint effect on the mechanical properties and increase the bioactive potential. It was observed that the addition of the higher amount of selected substances, e.g., oregano oil and rosemary extract, caused a better flow of the polymer (the substances exhibit lubricant properties), which lowered the processing temperatures for the regranulation and cast extrusion process (Tables S1 and S2). All studied bioactive additives/plasticizers/PP systems are presented 
in Tables S3-S6 with notes indicating the most suitable system for further modification using the experience observed in the preparation of film with one and two additives compositions, the three-, four- and five-component additives premixes were prepared, each time testing their joint effect on the mechanical properties and increasing their bioactive potential (the effects of the selection of modifier systems are described in section later step by step in the work).

The FTIR spectra of oregano oil, cedar oil, neat PP and modified PP are presented in Figure 2.

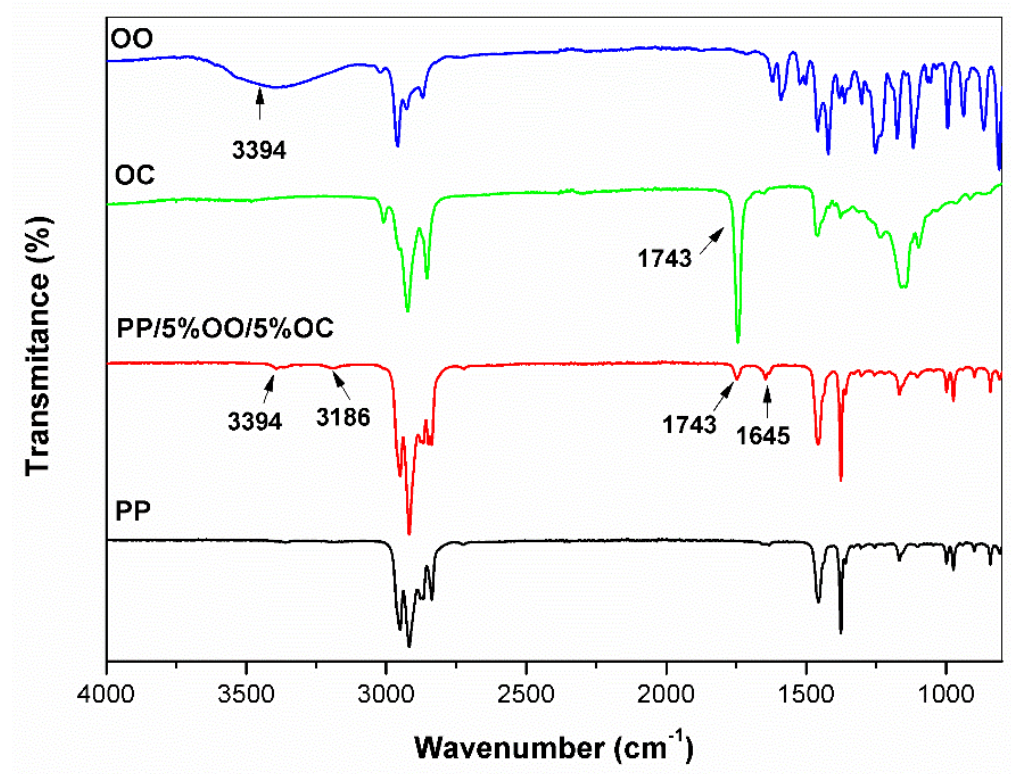

Figure 2. FTIR spectra for Compared spectrum selected additives (OO and CO), PP and modified PP film.

The samples were analyzed by FTIR spectroscopy. Spectral characteristics between films containing active substance (5\% oregano oil and 5\% cedar oil-Figure 2 ) and reference film (PP) exhibit that the major ingredients are present in the PP material. No shifts of the absorption bands were observed, which confirms the weak interaction between the introduced additives and the polymer matrix, facilitating their migration, thanks to which the biobacterial effect of the film is obtained. Comparing spectra difference between them was observed. In films containing oregano oil, the appearance of peaks from the hydroxyl groups $\left(3940 \mathrm{~cm}^{-1}\right)$ was noted. Additionally, a peak with a wavelength of $1743 \mathrm{~cm}^{-1}$ (carbonyl group) derived from cedar oil is observed (Figure 2) [22,33].

Most of the additives (plasticizers and antimicrobials) lowered the Young's modulus (ca. up to $20 \%$ ) and increased the tensile strength in the case of GTE and OO and elongation at break (ca. 15\%) (Table 1). This can be related to the better PP orientation of the film containing both bioactive additives and plasticizers that facilitated polymer processing causing, e.g., lubricating PP transportation through extruder $[35,36]$. During the regranulation process, the power load showed a lower value than in the case of extrusion of native PP granulate (decrease the resistance caused by an increase in the MFI of the modified re-granules Tables 1-3. The additives act as co-plasticizers and lubricants in both compounding and film cast extrusion processes, increasing melt flowing of the premixes leading to more effective processing. The film with $5 \%$ of plasticizer: Atmer121 characterized by the highest decrease in the Young's modulus (255 MPa), and almost highest increase in elongation at break $(762 \%)$. Samples with green tea extract and oregano oil at $5 \%$ and $10 \%$, respectively, were characterized by high values of Young's modulus and elongation at break, which can indicate the negative effect of monoterpenes presence on PP chains. Films containing plasticizing agents showed a greasy perspiration on their 
surface, while films with bioactive agent exhibited a specific fragrance, which indicates the migration of additives from PP material [35,36].

Table 1. The influence of single additive on the mechanical properties of various PP films.

\begin{tabular}{|c|c|c|c|c|c|c|}
\hline \multicolumn{2}{|c|}{ Active Substance } & \multirow{2}{*}{$\begin{array}{c}\text { Young's Modulus } \\
(M P a)\end{array}$} & \multirow{2}{*}{$\begin{array}{c}\text { Tensile Strength } \\
(M P a)\end{array}$} & \multirow{2}{*}{$\begin{array}{c}\text { Stress at Break } \\
(M P a)\end{array}$} & \multirow{2}{*}{$\begin{array}{c}\text { Elongation at Break } \\
(\%)\end{array}$} & \multirow{2}{*}{$\frac{\text { MFI }}{(\mathrm{g} / 10 \mathrm{~min})}$} \\
\hline Acronym & $(\%)$ & & & & & \\
\hline w. a. * & - & $400 \pm 2.1$ & $22 \pm 0.9$ & $18 \pm 0.7$ & $645 \pm 3.8$ & 9.000 \\
\hline A121 & 5 & $255 \pm 5.2$ & $20 \pm 1.2$ & $16 \pm 2.0$ & $762 \pm 8.2$ & 12.87 \\
\hline $\mathrm{CO}$ & 5 & $368 \pm 4.2$ & $21 \pm 1.1$ & $20 \pm 1.1$ & $648 \pm 6.8$ & 12.24 \\
\hline GTE & 5 & $676 \pm 8.1$ & $29 \pm 0.2$ & $27 \pm 0.1$ & $780 \pm 9.4$ & 7.56 \\
\hline RE & 5 & $397 \pm 6.3$ & $21 \pm 0.7$ & $19 \pm 2.1$ & $662 \pm 4.5$ & 8.88 \\
\hline \multirow{3}{*}{$\mathrm{OO}$} & 5 & $319 \pm 2.2$ & $22 \pm 0.8$ & $18 \pm 0.9$ & $665 \pm 3.6$ & 11.25 \\
\hline & 7.5 & $366 \pm 2.8$ & $26 \pm 1.4$ & $21 \pm 1.3$ & $636 \pm 6.7$ & 13.44 \\
\hline & 10 & $555 \pm 3.6$ & $30 \pm 1.7$ & $25 \pm 1.6$ & $623 \pm 4.8$ & 21.20 \\
\hline
\end{tabular}

*w. a.-without additives.

Table 2. The influence of double additives on the mechanical properties of PP film.

\begin{tabular}{|c|c|c|c|c|c|c|}
\hline \multicolumn{2}{|c|}{ Active Substance } & \multirow{2}{*}{$\begin{array}{c}\text { Young's Modulus } \\
(M P a)\end{array}$} & \multirow{2}{*}{$\begin{array}{c}\text { Tensile Strength } \\
(M P a)\end{array}$} & \multirow{2}{*}{$\begin{array}{c}\text { Stress at Break } \\
(\mathrm{MPa})\end{array}$} & \multirow{2}{*}{$\begin{array}{c}\text { Elongation at Break } \\
(\%)\end{array}$} & \multirow{2}{*}{$\frac{\text { MFI }}{(g / 10 \mathrm{~min})}$} \\
\hline Acronym & $(\%)$ & & & & & \\
\hline w. a * & - & $400 \pm 2.1$ & $22 \pm 0.9$ & $18 \pm 0.7$ & $645 \pm 3.8$ & 9.00 \\
\hline RE & 2.5 & \multirow{2}{*}{$398 \pm 3.2$} & \multirow{2}{*}{$22 \pm 1.8$} & \multirow{2}{*}{$22 \pm 1.8$} & \multirow{2}{*}{$628 \pm 5.1$} & \multirow{2}{*}{12.24} \\
\hline $\mathrm{CO}$ & 5.0 & & & & & \\
\hline $\mathrm{RE}$ & 5 & \multirow{2}{*}{$564 \pm 3.9$} & \multirow{2}{*}{$33 \pm 1.6$} & \multirow{2}{*}{$33 \pm 1.6$} & \multirow{2}{*}{$777 \pm 4.5$} & \multirow{2}{*}{10.92} \\
\hline $\mathrm{OO}$ & 5 & & & & & \\
\hline $\mathrm{OO}$ & 5 & \multirow{2}{*}{$746 \pm 6.1$} & \multirow{2}{*}{$37 \pm 2.9$} & \multirow{2}{*}{$37 \pm 2.9$} & \multirow{2}{*}{$940 \pm 5.8$} & \multirow{2}{*}{10.68} \\
\hline $\mathrm{MP}$ & 5 & & & & & \\
\hline $\mathrm{RE}$ & 2.5 & \multirow{2}{*}{$700 \pm 8.3$} & \multirow{2}{*}{$35 \pm 1.7$} & \multirow{2}{*}{$35 \pm 1.7$} & \multirow{2}{*}{$178 \pm 7.9$} & \multirow{2}{*}{10.32} \\
\hline A121 & 2.5 & & & & & \\
\hline RE & 5 & \multirow{2}{*}{$790 \pm 10.0$} & \multirow{2}{*}{$31 \pm 2.5$} & \multirow{2}{*}{$31 \pm 2.5$} & \multirow{2}{*}{$986 \pm 11.3$} & \multirow{2}{*}{11.76} \\
\hline A121 & 5 & & & & & \\
\hline $\mathrm{OO}$ & 5 & \multirow{2}{*}{$432 \pm 4.2$} & \multirow{2}{*}{$31 \pm 4.1$} & \multirow{2}{*}{$30 \pm 4.3$} & \multirow{2}{*}{$866 \pm 06.7$} & 1572 \\
\hline $\mathrm{CO}$ & 5 & & & & & $15 . / 2$ \\
\hline GTE & 5 & 560 & 25 & 11 & 8 & 972 \\
\hline $\mathrm{CO}$ & 5 & 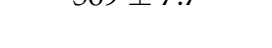 & $2+2.0$ & $19 \perp 1.0$ & (34. & 9.12 \\
\hline GTE & 5 & $401+25$ & $27+23$ & & $006+73$ & \\
\hline A121 & 5 & $491 \pm 0.0$ & $27 \pm 2.0$ & $23 \pm 0<.1$ & $300 \pm$. & 9.12 \\
\hline GTE & 5 & $360+41$ & $20+09$ & $16+10$ & 689 & 084 \\
\hline $\mathrm{OO}$ & 5 & S I. & $20+0$. & $10+1.0$ & 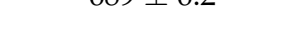 & . \\
\hline
\end{tabular}


Table 3. The effect of multi additives mixtures on the mechanical properties of polypropylene (PP) films.

\begin{tabular}{|c|c|c|c|c|c|c|}
\hline \multicolumn{2}{|c|}{ Active Substance } & \multirow{2}{*}{$\begin{array}{c}\text { Young's Modulus } \\
(M P a)\end{array}$} & \multirow{2}{*}{$\begin{array}{c}\text { Tensile Strength } \\
(M P a)\end{array}$} & \multirow{2}{*}{$\begin{array}{c}\text { Stress at Break } \\
(M P a)\end{array}$} & \multirow{2}{*}{$\begin{array}{c}\text { Elongation at Break } \\
(\%)\end{array}$} & \multirow{2}{*}{$\frac{\text { MFI }}{(g / 10 \mathrm{~min})}$} \\
\hline Acronym & $(\%)$ & & & & & \\
\hline w. a * & - & $400 \pm 2.1$ & $22 \pm 0.9$ & $18 \pm 0.7$ & $645 \pm 3.8$ & 9.00 \\
\hline $\mathrm{OO}$ & 5 & \multirow{3}{*}{$582 \pm 5.4$} & \multirow{3}{*}{$30 \pm 2.9$} & \multirow{3}{*}{$30 \pm 2.0$} & \multirow{3}{*}{$841 \pm 6.7$} & \multirow{3}{*}{12.72} \\
\hline RE & 2.5 & & & & & \\
\hline $\mathrm{MP}$ & 2.5 & & & & & \\
\hline $\mathrm{OO}$ & 5 & \multirow{3}{*}{$791 \pm 7.2$} & \multirow{3}{*}{$41 \pm 1.3$} & \multirow{3}{*}{$41 \pm 1.3$} & \multirow{3}{*}{$1137 \pm 11.9$} & \multirow{3}{*}{11.52} \\
\hline GTE & 2.5 & & & & & \\
\hline $\mathrm{CO}$ & 1.75 & & & & & \\
\hline MP & 2.5 & \multirow{3}{*}{$521 \pm 3.4$} & \multirow{3}{*}{$30 \pm 2.6$} & \multirow{3}{*}{$38 \pm 2.4$} & \multirow{3}{*}{$936 \pm 8.2$} & \multirow{3}{*}{9.60} \\
\hline $\mathrm{OO}$ & 5 & & & & & \\
\hline RE & 2.5 & & & & & \\
\hline GTE & 2.5 & \multirow{4}{*}{$655 \pm 6.3$} & \multirow{4}{*}{$30 \pm 3.8$} & \multirow{4}{*}{$23 \pm 1.7$} & \multirow{4}{*}{$964 \pm 5.7$} & \multirow{4}{*}{10.68} \\
\hline $\mathrm{MP}$ & 2.5 & & & & & \\
\hline $\mathrm{OO}$ & 5 & & & & & \\
\hline RE & 2.5 & & & & & \\
\hline MP & 1 & \multirow{4}{*}{$488 \pm 3.2$} & \multirow{4}{*}{$30 \pm 2.9$} & \multirow{4}{*}{$27 \pm 2.5$} & \multirow{4}{*}{$978 \pm 8.1$} & \multirow{4}{*}{11.04} \\
\hline $\mathrm{OO}$ & 5 & & & & & \\
\hline $\mathrm{RE}$ & 2.5 & & & & & \\
\hline $\mathrm{CO}$ & 1.75 & & & & & \\
\hline GTE & 2.5 & \multirow{5}{*}{$574 \pm 5.5$} & \multirow{5}{*}{$30 \pm 1.1$} & & & \\
\hline MP & 1 & & & & & \\
\hline $\mathrm{OO}$ & 5 & & & $24 \pm 3.7$ & $929 \pm 7.0$ & 11.74 \\
\hline $\mathrm{RE}$ & 2.5 & & & & & \\
\hline $\mathrm{CO}$ & 1.75 & & & & & \\
\hline
\end{tabular}

${ }^{*}$ w. a.-without additives.

The minimum inhibitory concentration (MIC) of antimicrobial substances such as $\mathrm{OO}$, RE, GTE and MP ranged from 2.5 to $0.02 \mathrm{mg} / \mathrm{mL}$. The MIC of oregano oil was $0.63 \mathrm{mg} / \mathrm{mL}$ against $P$. putida and P. expansum, $0.31 \mathrm{mg} / \mathrm{mL}$, against S. aureus, B. subtilis. E. coli, C. albicans and F. oxysporum, $0.08 \mathrm{mg} / \mathrm{mL}$ for $A$. brasiliensis and $0.02 \mathrm{mg} / \mathrm{mL}$ A. alternata. The MIC of rosemary extract was $1.25 \mathrm{mg} / \mathrm{mL}$ against $P$. expansum, $0.31 \mathrm{mg} / \mathrm{mL}$ for $S$. aureus and F. oxysporum, $0.16 \mathrm{mg} / \mathrm{mL}$ P. putida, E. coli, A. brasiliensis and $0.04 \mathrm{mg} / \mathrm{mL}$ for the most sensitive species in our test was A. alternata. The MIC of GTE was $2.5 \mathrm{mg} / \mathrm{mL}$ against P. expansum, $1.25 \mathrm{mg} / \mathrm{mL}$ for A. brasiliensis, $0.16 \mathrm{mg} / \mathrm{mL}$ B. subtilis and E. coli, $0.08 \mathrm{mg} / \mathrm{mL}$ S. aureus and A. alternata, $0.04 \mathrm{mg} / \mathrm{mL}$ against P. putida and C. albicans. The MIC of MP was $2.5 \mathrm{mg} / \mathrm{mL}$ against S. aureus and P. putida, $0.31 \mathrm{mg} / \mathrm{mL}$ for P. putida, E. coli, C. albicans, P. expansum, $0.16 \mathrm{~g} / \mathrm{mL}$ against $A$. alternata and $0.02 \mathrm{mg} / \mathrm{mL}$ for $A$. brasiliensis. The inhibitory concentrations, caused similar decrease $(p>0.05)$ in the counts of all assessed groups of the microorganisms.

Single additive films with active substance have antimicrobial properties against bacteria (Table S4), yeast and molds (Table S5). Films containing only commercial plasticizer Atmer121 (5\%) did not exhibit any biocidal properties. Films with CO (5\%) had no effect against all tested bacteria but exhibited the 1-log reduction in the number of Alternaria alternata (the number of the cells was $5.33 \times 10^{3} \mathrm{cfu} / \mathrm{mL}$ ) after surface direct contact test compared to the control sample $\left(1.78 \times 10^{4} \mathrm{cfu} / \mathrm{mL}\right)$. Films containing GTE $(5 \%)$ 
demonstrated antimicrobial activity against Pseudomonas putida, which had total growth reduction (control was $2.28 \times 10^{8} \mathrm{cfu} / \mathrm{mL}$ ) and 1-log reduction in growth Bacillus subtilis $\left(1.33 \times 10^{6} \mathrm{cfu} / \mathrm{mL}\right)$ compared to control $\left(1.47 \times 10^{7} \mathrm{cfu} / \mathrm{mL}\right)$. Films with $\mathrm{RE}(5 \%)$ had no effect against all bacteria strains, but inhibited growth of molds such as $A$. alternata $\left(2.00 \times 10^{3} \mathrm{cfu} / \mathrm{mL}\right)$ and Fusarium oxysporum $\left(2.00 \times 10^{3} \mathrm{cfu} / \mathrm{mL}\right)$ compared to the control sample $\left(5.47 \times 10^{5} \mathrm{cfu} / \mathrm{mL}\right)$. Foils with additive $\mathrm{OO}(5 \%)$ reduced 1-1.5 log growth of $A$. alternata $\left(4.2 \times 10^{3} \mathrm{cfu} / \mathrm{mL}\right)$ and F. oxysporum $\left(8.9 \times 10^{3} \mathrm{cfu} / \mathrm{mL}\right)$. OO $(7.5 \%)$ reduced growth 1-1.5 $\log$ B. subtilis $\left(1.23 \times 10^{6} \mathrm{cfu} / \mathrm{mL}\right)$ and P. putida $\left(1.65 \times 10^{7} \mathrm{cfu} / \mathrm{mL}\right)$, more than 2-log reduction in growth Candida albicans $\left(3.2 \times 10^{3} \mathrm{cfu} / \mathrm{mL}\right)$ compared to the control sample $\left(2.75 \times 10^{6} \mathrm{cfu} / \mathrm{mL}\right)$, A. alternaria $\left(6.5 \times 10^{2} \mathrm{cfu} / \mathrm{mL}\right)$, F. oxysporum $\left(1.87 \times 10^{4} \mathrm{cfu} / \mathrm{mL}\right)$ and total reduction in growth Staphylococcus aureus. Oregano oil (10\%) reduced growth Escherichia coli $\left(7.55 \times 10^{7} \mathrm{cfu} / \mathrm{mL}\right)$ compared to the control $\left(3.68 \times 10^{8} \mathrm{cfu} / \mathrm{mL}\right)$ and had total reduction in growth $S$. aureus, C. albicans, A. alternaria and F. oxysporum.

Most of the added additives (bioactive and plasticizing) increased tensile strength, Young's modulus and elongation at break, similar to the case of film modified with a single additive (Tables 2 and 3). This may be due to the better polymer chains orientation in the film with the addition of both bioactive additives and plasticizers. The processing behavior of PP with the additive mixtures is the same as in the case of PP with single additives. Almost all samples containing additives were exhibit higher values of Young's modulus and elongation at break than neat PP films. It can be caused by monoterpens (present in essential oils) able to cut the PP chains while plasticizing the film during thermos processing. Films with both plasticizing and bioactive agents showed the greasy droplets on the surface and a more smellable compared to mono systems, that can be related to the faster migration of additives from the material [35,37].

The antimicrobial properties for 10 various compositions of double-additive extruded films with different concentration of active substances were tested and summarized for bacteria (Table S9), yeast and molds (Table S10). The first mixture system of RE $(2.5 \%)$ with CO $(2.5 \%)$ had no effect against all bacteria strains; however, it did reduce by 1-1.5-log growth of F. oxysporum $\left(5.63 \times 10^{3} \mathrm{cfu} / \mathrm{mL}\right)$ compared to the control $(5.47 \times 10 \mathrm{cfu} / \mathrm{mL})$. While increasing the concentration of RE to $5 \%$ at constant amount of $\mathrm{CO}(2.5 \%)$ the reduction in B. subtilis $\left(3.85 \times 10^{4} \mathrm{cfu} / \mathrm{mL}\right)$ while control was $\left(1.47 \times 10^{7} \mathrm{cfu} / \mathrm{mL}\right)$, total reduction in $S$. aureus and F. oxysporum was obtained. Films with RE (5\%) OO (5\%) decreased the number of P. putida by $1-\log \left(7.13 \times 10^{7} \mathrm{cfu} / \mathrm{mL}\right) \mathrm{com}-$ pared control $\left(2.28 \times 10^{8} \mathrm{cfu} / \mathrm{mL}\right)$ and F. oxysporum $\left(2.48 \times 10^{3} \mathrm{cfu} / \mathrm{mL}\right)$, by $2-\log$ B. subtilis $\left(3.35 \times 10^{5} \mathrm{cfu} / \mathrm{mL}\right)$, E. coli $\left(1.75 \times 10^{5} \mathrm{cfu} / \mathrm{mL}\right)$ while control was $\left(3.68 \times 10^{8} \mathrm{cfu} / \mathrm{mL}\right)$ and C. albicans $\left(1.45 \times 10^{4} \mathrm{cfu} / \mathrm{mL}\right)$ compared control samples $\left(7.50 \times 10^{3} \mathrm{cfu} / \mathrm{mL}\right)$ and total reduction in $S$. aureus and $A$. alternata. Foil OO (5\%) with MP (5\%) reduced by 1-1.5-log growth B. subtilis $\left(3.35 \times 10^{5} \mathrm{cfu} / \mathrm{mL}\right)$, P. putida $\left(3.75 \times 10^{7} \mathrm{cfu} / \mathrm{mL}\right)$ and A. alternata $\left(2.55 \times 10^{3} \mathrm{cfu} / \mathrm{mL}\right)$ when the control for this molds was $\left(1.78 \times 10^{4} \mathrm{cfu} / \mathrm{mL}\right)$, by $2-\log$ of $C$. albicans $\left(2.06 \times 10^{4} \mathrm{cfu} / \mathrm{mL}\right)$ and F. oxysporum $\left(3.03 \times 10^{4} \mathrm{cfu} / \mathrm{mL}\right)$ and total reduction in $S$. aureus. Next sample RE (2.5\%) with A121 (2.5\%) reduced only F. oxysporum by $1-\log \left(1.46 \times 10^{4} \mathrm{cfu} / \mathrm{mL}\right)$ and RE $(5 \%)$ with A121 (5\%) reduced by $1-$ $\log$ P. putida $\left(3.88 \times 10^{7} \mathrm{cfu} / \mathrm{mL}\right)$. Foil OO $(5 \%)$ with $\mathrm{CO}(5 \%)$ had total reduction in all bacteria strains and C. albicans, A. alternata and F. oxysporum, 1-log reduction number of Aspergillus brasiliensis $\left(1.75 \times 10^{2} \mathrm{cfu} / \mathrm{mL}\right)$ compared to control $\left(3.78 \times 10^{3} \mathrm{cfu} / \mathrm{mL}\right)$. Films GTE (5\%) with CO (5\%) reduced by 1-log number of B. subtilis $\left(1.33 \times 10^{6} \mathrm{cfu} / \mathrm{mL}\right)$, S. aureus $\left(4.95 \times 10^{4} \mathrm{cfu} / \mathrm{mL}\right)$ compared to control $\left(6.83 \times 10^{5} \mathrm{cfu} / \mathrm{mL}\right)$ and total reduction in P. putida. Whereas foil GTE (5\%) with A121 (5\%) reduced B. subtilis by 1-log $\left(6.25 \times 10^{6} \mathrm{cfu} / \mathrm{mL}\right)$ and had total reduction in S. aureus and P. putida. Foil GTE (5\%) with OO (\%) also reduced B. subtilis by $1-\log \left(1.43 \times 10^{6} \mathrm{cfu} / \mathrm{mL}\right)$, by 2-log F. oxysporum $\left(6.75 \times 10^{2} \mathrm{cfu} / \mathrm{mL}\right)$ and had total reduction in S. aureus, P. putida, C. albicans and A. alternata.

Results obtained for 6 different films with mixtures active substances are presented in Table S11 for bacteria and in Table S12 for yeast and molds. First film containing OO 
(5\%), RE (2.5\%), MP (2.5\%) reduced number by 1-log A. alternata $\left(6.5 \times 10^{2} \mathrm{cfu} / \mathrm{mL}\right)$ when the control was $\left(1.78 \times 10^{4} \mathrm{cfu} / \mathrm{mL}\right)$, F. oxysporum $\left(8.25 \times 10^{4} \mathrm{cfu} / \mathrm{mL}\right)$ compared to control $\left(5.47 \times 10^{5} \mathrm{cfu} / \mathrm{mL}\right)$, by 2-log P. putida $\left(2.77 \times 10^{6} \mathrm{cfu} / \mathrm{mL}\right)$ compared to control $\left(2.28 \times 10^{8} \mathrm{cfu} / \mathrm{mL}\right)$ and total number of $S$. aureus and C. albicans. Foil OO (5\%), RE $(2.5 \%) \mathrm{CO}(1.75 \%)$ reduced number by 1-log of $A$. brasiliensis $\left(5.5 \times 10^{2} \mathrm{cfu} / \mathrm{mL}\right)$ while the control was $\left(5.21 \times 10^{3} \mathrm{cfu} / \mathrm{mL}\right)$, Penicilium expansum $\left(9.25 \times 10^{3} \mathrm{cfu} / \mathrm{mL}\right)$ compared to control $\left(1.97 \times 10^{4} \mathrm{cfu} / \mathrm{mL}\right)$, more than 2-log reduction number of B. subtilis $\left(3.10 \times 10^{4}\right.$ $\mathrm{cfu} / \mathrm{mL})$ when the control was $\left(1.47 \times 10^{7} \mathrm{cfu} / \mathrm{mL}\right)$ P. putida $\left(5.77 \times 10^{6} \mathrm{cfu} / \mathrm{mL}\right)$ and total reduction in E. coli, S. aureus, C. albicans, A. alternata and F. oxysporum. Film MP (2.5\%), OO $(5 \%)$, GTE $(2.5 \%)$ reduced number by 1-log A. alternata $\left(6.5 \times 10^{2} \mathrm{cfu} / \mathrm{mL}\right)$, F. oxysporum $\left(8.25 \times 10^{4} \mathrm{cfu} / \mathrm{mL}\right)$, by $2-\log$ P. putida and total number of S. aureus and C. albicans. Foil GTE $(2.5 \%)$, MP (2.5\%), OO (5\%), RE (2.5\%) reduced number by 1-log of B. subtilis (1.43 $\left.\times 10^{6} \mathrm{cfu} / \mathrm{mL}\right)$, by $2-\log$ F. oxysporum $\left(6.75 \times 10^{4} \mathrm{cfu} / \mathrm{mL}\right)$ and total number of S. aureus, P. putida, C. albicans and A. alternata. Next sample MP (1\%), OO (5\%), RE (2.5\%), CO (1.75\%) reduced number by $1-\log$ of $B$. subtilis $\left(1.12 \times 10^{6} \mathrm{cfu} / \mathrm{mL}\right)$ and total number of $E$. coli, S. aureus, P. putida, C. albicans, A. alternata and F. oxysporum. Last film GTE (2.5\%), MP (1\%), $\mathrm{OO}(5 \%), \mathrm{RE}(2.5 \%) \mathrm{CO}(1.75 \%)$ reduced number by $1-\log$ of B. subtilis $\left(1.12 \times 10^{6} \mathrm{cfu} / \mathrm{mL}\right)$ and total number of S. aureus, P. putida, C. albicans, A. alternata and F. oxysporum. Similar results are described in the literature [38-40]. The differences between the numbers of viable cells were not significant, as later confirmed by Duncan's test $(p>0.05)$. Figures 3-6 show the effect of active substances in the extruded films on different strains of bacteria, yeast and molds where there reduced number in growth in the largest number of films tested. A mixture of at least two active agents and with additives of a plasticizer works synergistically and enhances the release of the active substance from the film matrix. This contributes to a total reduction in the growth of tested microorganisms.

\section{Bacillus subtilis}

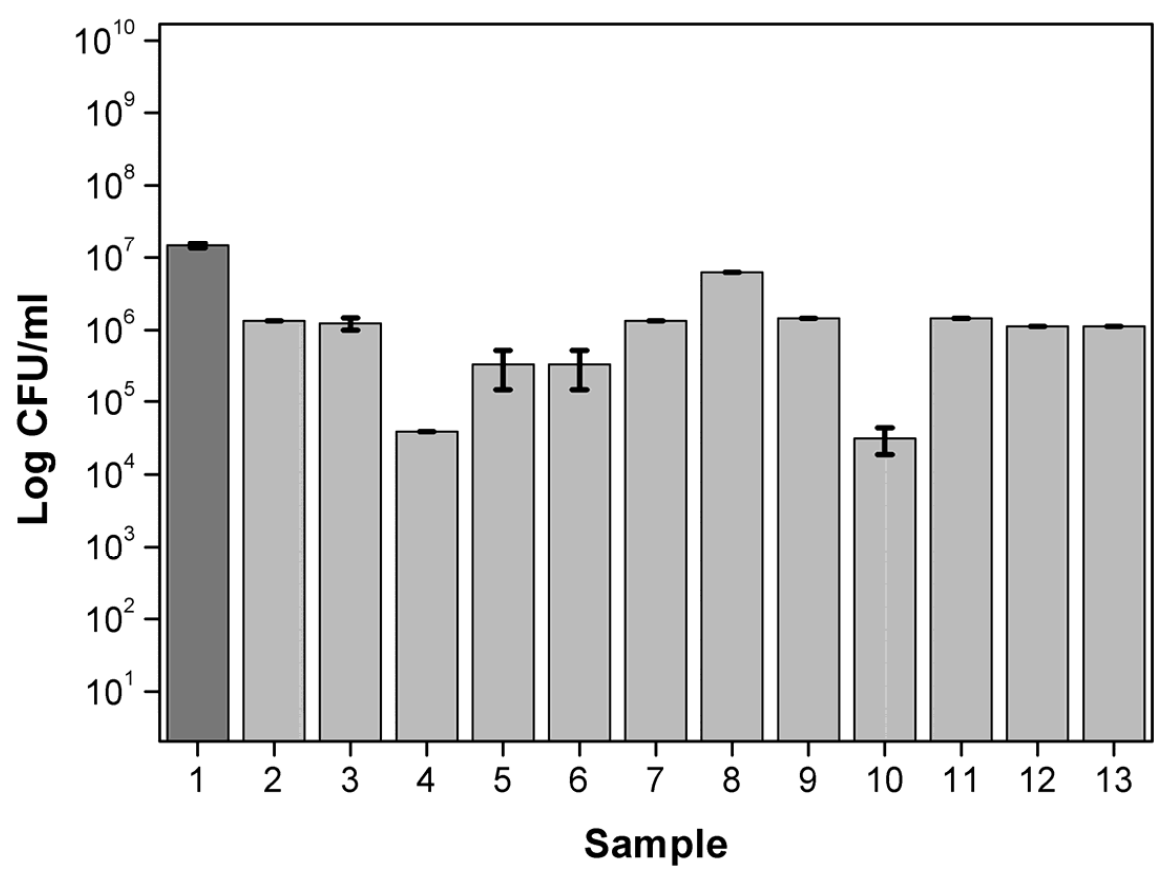

Figure 3. The influence of active substance on B. subtilis growth: 1-control, 2-GTE, 3-OO 7.5\%, 4RE,CO, 5-RE,OO, 6-OO,MP, 7-GTE,CO, 8-GTE,A121, 9-GTE,OO, 10-GTE,OO,RE,CO, 11-GTE,MP,OO,RE, 12-MP,OO,RE,CO, 13-GTE,MP,OO,RE,CO. 


\section{Bacillus subtilis}

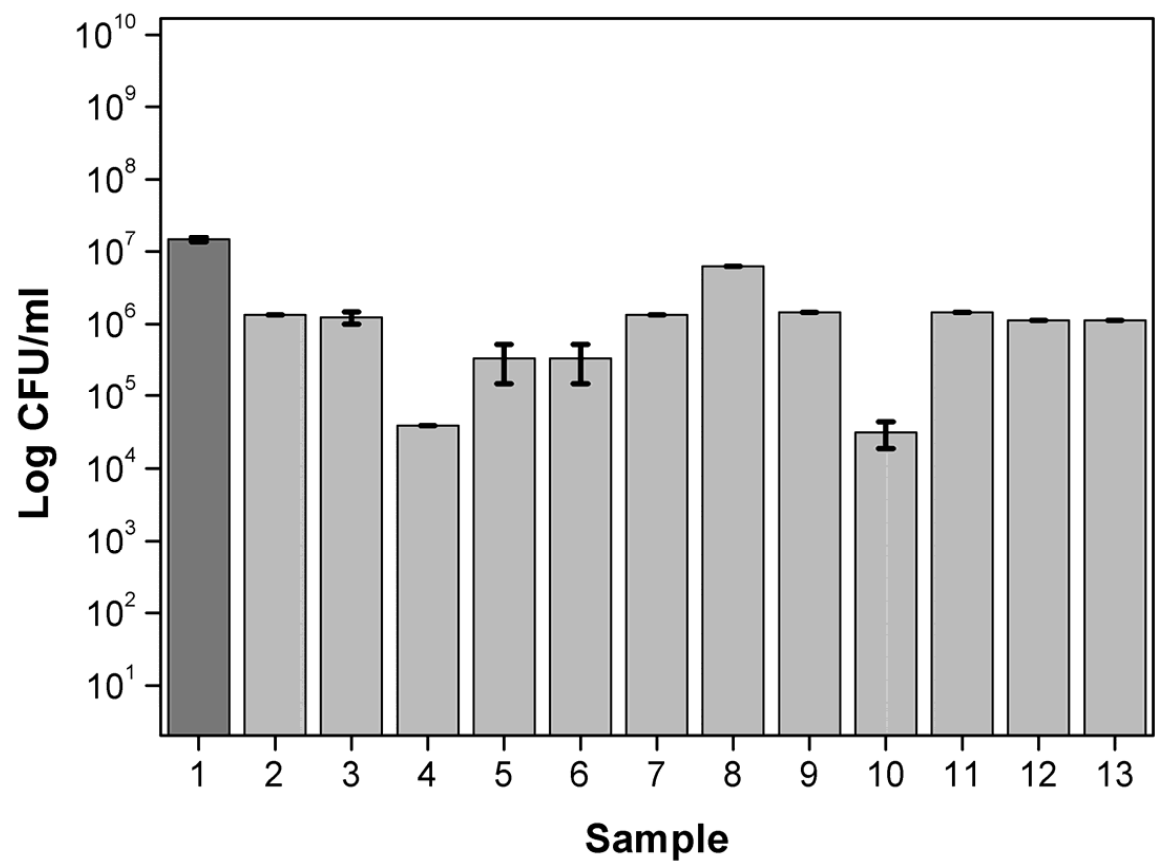

Figure 4. The influence of active substance on P. putida growth: 1-control, 2-OO 7.5\%, 3-RE,OO, 4-OO,MP, 5-RE,A121, 6-OO,RE,CO, 7-MP,OO,RE.

Alternaria alternata

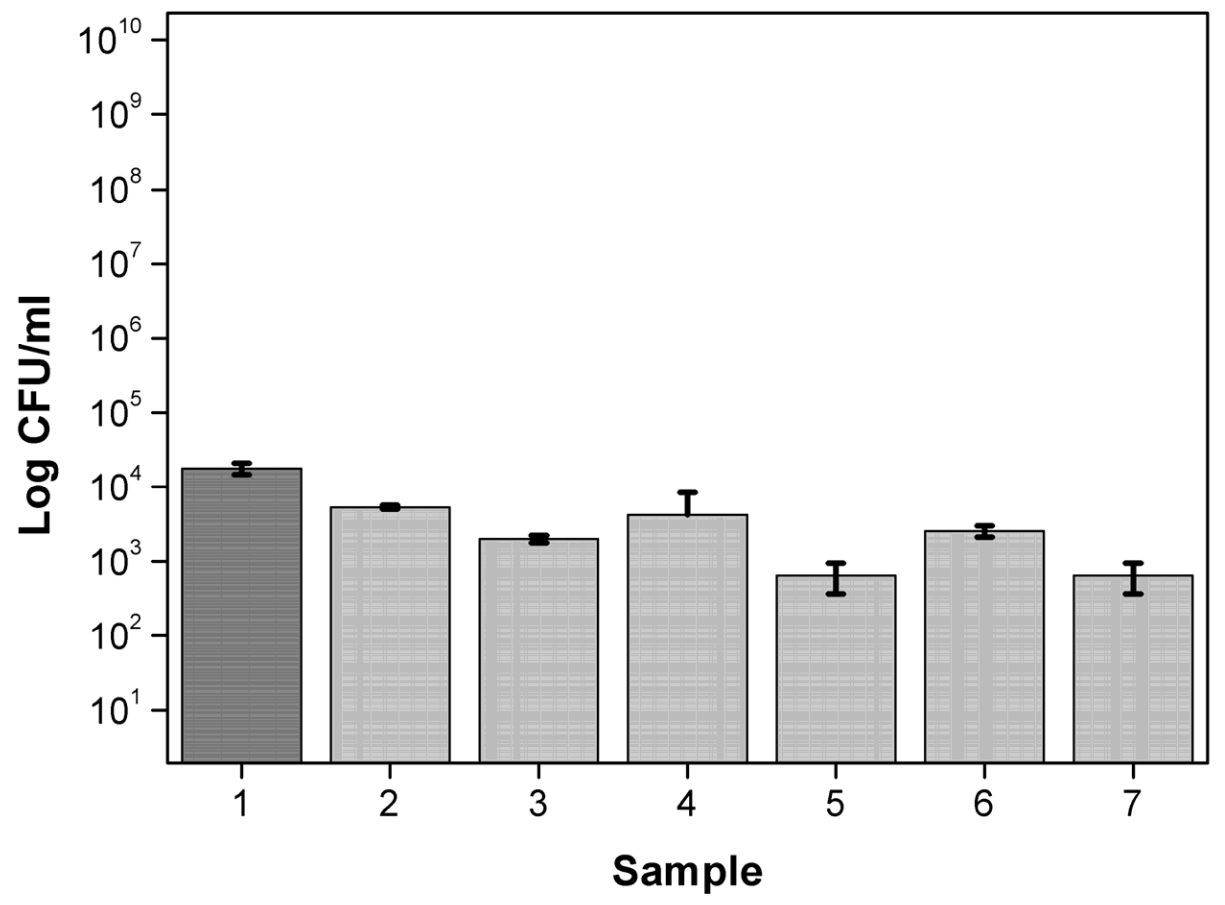

Figure 5. The influence of active substance on A. alternata growth: 1-control, 2-CO, 3-RE, 4-OO 5\%, 5-OO 7.5\%, 6-OO,MP, 7-OO,RE,MP. 


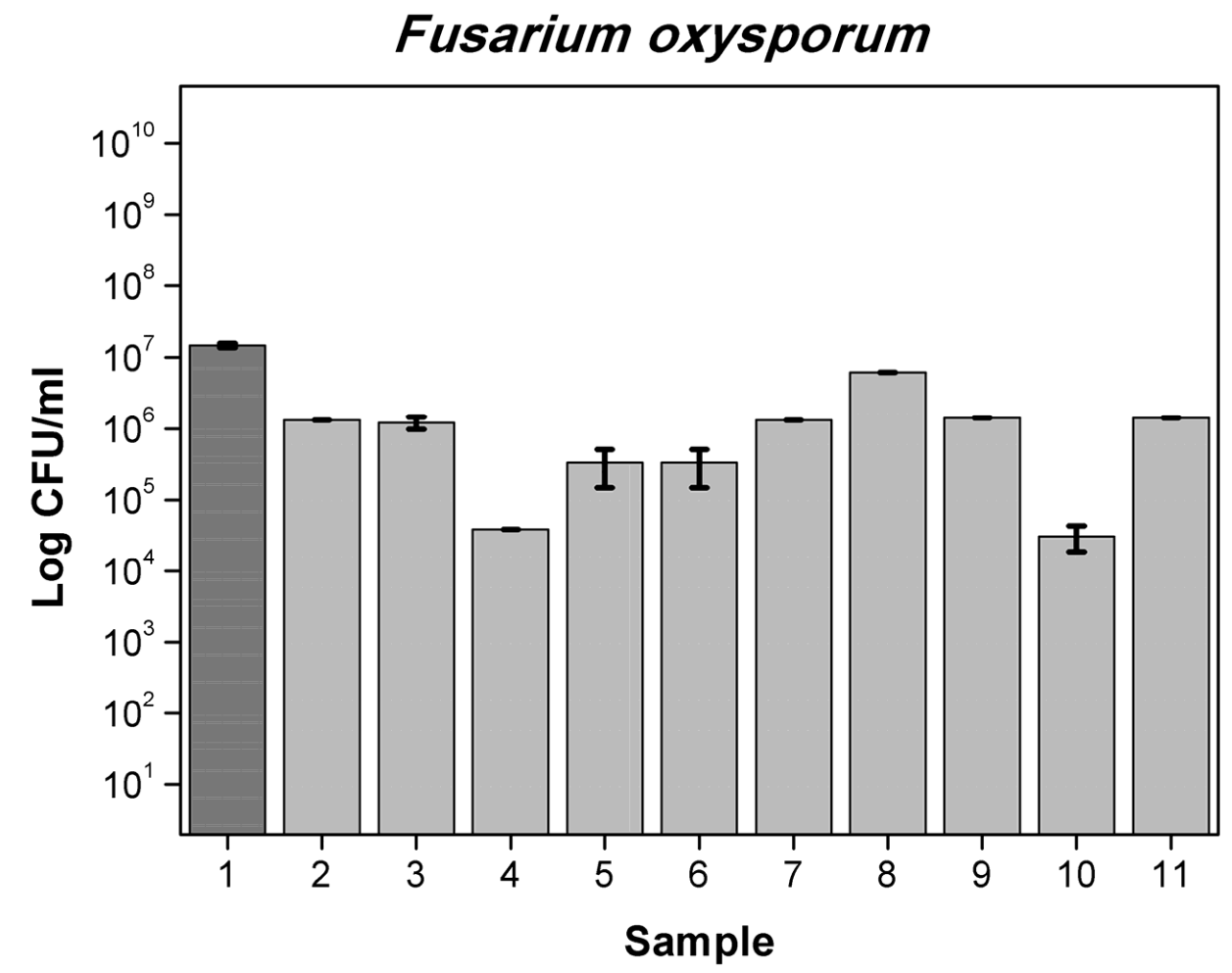

Figure 6. The influence of active substance on F. oxysporum growth: 1-control, 2-RE, 3-OO 5\%, 4-OO 7.5\%, 5-RE,CO, 6-RE,OO, 7-OO,MP, 8-RE,A121, 9-GTE,OO, 10-OO,RE,MP, 11-GTE,MP,OO,RE.

The obtained PP films have good hot-sealing properties (confirmed by the similar strength properties of the seal area compared to the non-sealed films-Table 4). The additive presence affect mechanical properties; Young's modulus was at the level confirming the sealing of the obtained material. The mechanical properties of the sealed parts are closely related to the amount of plasticizing additives introduced into the polymer matrix. The higher the amount of plasticizer, the weaker the sealing strength. Most likely, it can be caused by the phase separation process and higher rate of migration of plasticizers with bioactive agents onto the film surface. This phenomenon (desirable due to the biocidal properties of the film) disturbs the sealing, creating the "easy peel" effect in the sealed places. Ruiz-Cabello and co-authors observed that films containing oregano oil were more flexible, highlighting the plasticization effect of the natural extracts [41].

For the confirmation of the possibility packages formation from our new materials, the prototypes of perforated bags with tomatoes inside were prepared and tested (Figure 7). We compared control PP bags with MP, OO, RE, CO exhibiting the biggest antimicrobial properties. We observed that tomatoes in control had sign of molds, but PP with active substances was still fresh without changes in the appearance. The total number of microorganisms after 14 days storage in control bag PP was $2 \times 10^{4} \mathrm{cfu} / \mathrm{mL}$, but for bags with MP, $\mathrm{OO}, \mathrm{RE}, \mathrm{CO}$ was $1.45 \times 10^{1} \mathrm{cfu} / \mathrm{mL}$. It shown that releasing of active substances reduced growth microorganism on tomatoes surface.

Our team will continue storage test in the future. Ramos and co-authors suggest that carvacrol show a potential use as antioxidants for active packaging to extend the shelf life of food products [42]. This effect was obtained by filling the film with a biocidal compound relatively high, which directly affects the bioactivity time of the film. In the future, this will increase the production costs of the film, but we believe that storage time of vegetables and fruits packed this way will be prolonged and thus the extended shelf life, will compensate increased packaging production costs. 
Table 4. Influence of multi additives mixtures on the hot-sealability of polypropylene (PP) films.

\begin{tabular}{|c|c|c|c|c|c|}
\hline \multicolumn{2}{|c|}{ Active Substance } & \multirow{2}{*}{$\begin{array}{c}\text { Young's Modulus } \\
(M P a)\end{array}$} & \multirow{2}{*}{$\begin{array}{c}\text { Tensile Strength } \\
(M P a)\end{array}$} & \multirow{2}{*}{$\begin{array}{c}\text { Stress at Break } \\
(M P a)\end{array}$} & \multirow{2}{*}{$\begin{array}{c}\text { Elongation at Break } \\
(\%)\end{array}$} \\
\hline Acronym & $(\%)$ & & & & \\
\hline w. a * & - & $429 \pm 3.9$ & $16 \pm 0.82$ & $12 \pm 0.42$ & $25 \pm 1.14$ \\
\hline $\mathrm{RE}$ & 5 & \multirow{2}{*}{$100 \pm 1.5$} & \multirow{2}{*}{$2 \pm 0.12$} & \multirow{2}{*}{$4 \pm 0.53$} & \multirow{2}{*}{$2 \pm 0.21$} \\
\hline $\mathrm{OO}$ & 5 & & & & \\
\hline $\mathrm{OO}$ & 5 & \multirow{2}{*}{$18 \pm 0.9$} & \multirow{2}{*}{$1 \pm 0.11$} & \multirow{2}{*}{$1 \pm 0.07$} & \multirow{2}{*}{$85 \pm 1.96$} \\
\hline $\mathrm{CO}$ & 5 & & & & \\
\hline $\mathrm{RE}$ & 2.5 & \multirow{3}{*}{$88 \pm 3.3$} & \multirow{3}{*}{$2 \pm 0.09$} & \multirow{3}{*}{$4 \pm 0.18$} & \multirow{3}{*}{$4 \pm 0.12$} \\
\hline $\mathrm{OO}$ & 5 & & & & \\
\hline $\mathrm{CO}$ & 1.75 & & & & \\
\hline $\mathrm{RE}$ & 2,5 & \multirow{4}{*}{$86 \pm 2.6$} & \multirow{4}{*}{$5 \pm 0.31$} & \multirow{4}{*}{$10 \pm 0.11$} & \multirow{4}{*}{$23 \pm 0.56$} \\
\hline $\mathrm{OO}$ & 5 & & & & \\
\hline $\mathrm{CO}$ & 1.75 & & & & \\
\hline MP & 1 & & & & \\
\hline
\end{tabular}

${ }^{*}$ w. a.-without additives.

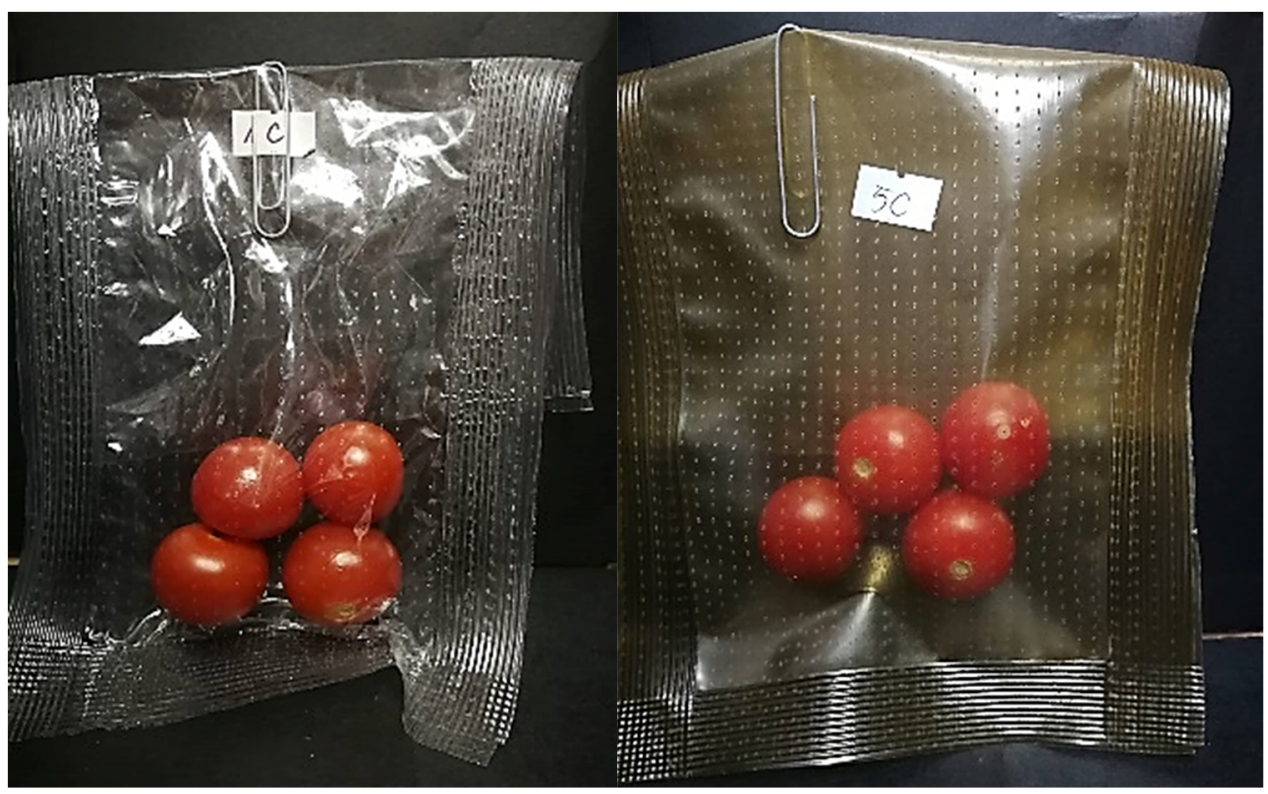

Figure 7. Examples of tomatoes in bag.

\section{Conclusions}

This paper presents novel polypropylene-based films modified with active agents and plasticizers with bioactive properties. In order to demonstrate their influence on the functional properties of the film and the antimicrobial potential, films modified with mono, double and mixtures of selected additives were obtained.

The best four compositions of additives were selected; RE with $\mathrm{OO}, \mathrm{OO}$ with $\mathrm{OC}$, $\mathrm{OO}, \mathrm{RE}, \mathrm{CO}$ and $\mathrm{MP}, \mathrm{OO}, \mathrm{RE}, \mathrm{CO}$ acting as both active agents and plasticizers. Thanks to the gradual release from the polymer material, the biocidal activity was enhanced. Films with only bioactive agent exhibited lower or no biocidal properties. In general cases, only higher concentrations of active substances were more effective through microbials. This allowed for the reduction in bioactive additives while extending the biocidal effect. Among all additives presented in this study, oregano oil was the most bioactive. Moreover, OO with cedar oil showed the highest level of protection against microorganisms amongst 
studied materials, and thus potentially prevents food spoilage. Initial attempts to obtain a sealable bag from new materials have shown their weaker mechanical properties compared to unmodified PP foil. This is related to the rate of "exudation" of the plasticizer and can be easily tunable by its concentration. The sealed areas obtained in this method are characterized by the so-called easy-peel effect, which may be an interesting feature for some film applications.

PP films extruded with double and multi active substances have a wide scope pf activity against bacteria, yeast and molds, which are typical microflora responsible for the spoilage of fresh tomatoes. Storage tests have shown that packages with active substances inhibit the growth of microorganisms on the tomatoes' surface. They could be potentially applied in the packaging industry as food direct-contact materials with the ability to extend the freshness of selected fresh-market products.

The increased biocidal effect in the case of some PP films modified with special processing additives may be caused by faster migration of the active agent with the plasticizers' presence. This phenomenon affects higher biocidal concentration of active agents in a shorter time on the PP film surface.

PP films with biocidal properties presented in this work show a great deal of application potential. In the future, they will certainly become an inspiration for the synergy of plasticizers and biocidal substances, and for the development of other types of polymers, especially based on biodegradable materials, e.g., PLA or PHA.

Supplementary Materials: The following are available online at https: / www.mdpi.com/article/ 10.3390/polym13203478/s1, Table S1: Parameters of the PP regranulation processor, Table S2: Cast processing parameters of modified PP film extrusion, Table S3: Modifications of PP film by plasticizers and bioactives-single additives, Table S4: Modifications of PP film by plasticizers and bioactives—double additives, Table S5: Modifications of PP film by plasticizers and bioactives—triple additives, Table S6: Modifications of PP film by plasticizers and bioactives-multi additives, Table S7: Antimicrobial activity of single additives extruded PP films against bacteria using ASTM E 2180-18 procedure, Table S8: Antimicrobial activity of single additives extruded PP films against yeast and molds, Table S9: Antimicrobial activity of double additives extruded PP films against bacteria using ASTM E 2180-18 procedure, Table S10: Results obtained using ASTM E 2180-18 for double additives active substance extruded films against yeast and molds, Table S11: Results using ASTM E 2180-18 for different films multi additives mixtures against bacteria, Table S12: Results using ASTM E 2180-18 for different films multi additives mixtures against yeast and molds, Figure S1: Experimental design.

Author Contributions: A.K.A.: Experimental design, data collection, analysis, manuscript preparation, manuscript revision; U.K.: Contributed to experimental design, literature review, data collection and analysis; M.S.: technical implementation, data collection, analysis, manuscript revision; P.D.: Contributed to experimental design and data collection, manuscript preparation; M.P.: literature and conception review, writing - review and editing K.K.: literature review, technical implementation; A.B.: final approval of the completed article, project administration. All authors have read and agreed to the published version of the manuscript.

Funding: This research was funded by the National Center for Research and Development (NCBiR) as part of the CORNET initiative.

Institutional Review Board Statement: Not applicable.

Informed Consent Statement: Not applicable.

Data Availability Statement: The data presented in this study are available on request from the corresponding author.

Acknowledgments: This research project "FreshInPac-The development of antimicrobial packaging materials" is carried out under the auspices of the Polish National Center of Research and Development (NCBiR).

Conflicts of Interest: The authors declare no conflict of interest. 


\section{References}

1. Gaikwad, K.K.; Lee, S.M.; Lee, J.S.; Lee, Y.S. Development of antimicrobial polyolefin films containing lauroyl arginate and their use in the packaging of strawberries. J. Food Meas. Charact. 2017, 11, 1706-1716. [CrossRef]

2. Busolo, M.A.; Lagaron, J.M. Oxygen scavenging polyolefin nanocomposite films containing an iron modified kaolinite of interest in active food packaging applications. Innov. Food Sci. Emerg. Technol. 2012, 16, 211-217. [CrossRef]

3. Shanmugam, K.; Doosthosseini, H.; Varanasi, S.; Garnier, G.; Batchelor, W. Nanocellulose films as air and water vapour barriers: A recyclable and biodegradable alternative to polyolefin packaging. Sustain. Mater. Technol. 2019, 22, e00115. [CrossRef]

4. Sankari, A.; Swarna Priya, R.; Savitha, B.K. Seed packaging in vegetables. Biot. Res. Today 2020, 2, 853-858.

5. Bhargava, N.; Sharanagat, V.S.; Mor, R.S.; Kumar, K. Active and intelligent biodegradable packaging films using food and food waste-derived bioactive compounds: A review. Trends Food Sci. Technol. 2020, 105, 385-401. [CrossRef]

6. Bahrami, A.; Delshadi, R.; Assadpour, E.; Jafari, S.M.; Williams, L. Antimicrobial-loaded nanocarriers for food packaging applications. Adv. Colloid Interface Sci. 2020, 278, 102140. [CrossRef] [PubMed]

7. Romani, V.P.; Martins, V.G.; Goddard, J.M. Radical scavenging polyethylene films as antioxidant active packaging materials. Food Control 2020, 109, 106946. [CrossRef]

8. González-Romero, J.; Arranz-Arranz, S.; Verardo, V.; García-Villanova, B.; Guerra-Hernández, E.J. Bioactive compounds and antioxidant capacity of moringa leaves grown in spain versus 28 leaves commonly consumed in pre-packaged salads. Processes 2018, 8, 1297. [CrossRef]

9. Jafarzadeh, S.; Jafari, S.M.; Salehabadi, A.; Nafchi, A.M.; Kumar, U.S.U.; Khalil, H.A. Biodegradable green packaging with antimicrobial functions based on the bioactive compounds from tropical plants and their by-products. Trends Food Sci. Technol. 2020, 100, 262-277. [CrossRef]

10. Egodage, D.; Jayalath, H.; Samarasekara, A.; Amarasinghe, D.; Madushani, S.; Senerath, S. Novel antimicrobial nano coated polypropylene based materials for food packaging systems. In Proceedings of the Moratuwa Engineering Research Conference (MERCon), Moratuwa, Sri Lanka, 29-31 May 2017; pp. 88-92. [CrossRef]

11. Duma, M.; Alsina, I.; Dubova, L.; Erdberga, I. Quality of tomatoes during storage. ISHS Acta Hortic. 2017, 130-133. [CrossRef]

12. Farneti, B.; Zhang, W.; Witkowska, I.; Woltering, E. Effect of home-refrigerator storage temperature on tomato quality. Acta Hortic. 2010, 1191-1196. [CrossRef]

13. Feng, R.; Olsson, S.; Currie, M.; White, A.; Hallett, I.; De Silva, H.; Billing, D.; Kashuba, P.; Astill, M.; Kashuba, M.P. Effects of temperature conditions during transport and storage on tomato fruit quality. Acta Hortic. 2016, 29-34. [CrossRef]

14. Nyalala, S.; Wainwright, H. The shelf life of tomato cultivars at different storage temperatures. Trop. Sci. 1998, 38, 151-154.

15. Kizior, B.; Panek, J.J.; Jezierska, A. Essential oils. A description of their selected ingredients properties on the basis of molecular mod-eling methods. Ansthet. Cosmed. Med. 2020, 9, 501-508.

16. Del Campo, J.; Amiot, M.J.; Nguyen-The, C. Antimicrobial effect of rosemary extracts. J. Food Prot. 2000, 63, 1359-1368. [CrossRef]

17. Du, W.-X.; Olsen, C.; Avena-Bustillos, R.; McHugh, T.; Levin, C.; Mandrell, R.; Friedman, M. Antibacterial effects of allspice, garlic, and oregano essential oils in tomato films determined by overlay and vapor-phase methods. J. Food Sci. 2009, 74, M390-M397. [CrossRef]

18. Lu, M.; Dai, T.; Murray, C.K.; Wu, M.X. Bactericidal property of oregano oil against multidrug-resistant clinical isolates. Front Microbiol. 2018, 9, 2329. [CrossRef] [PubMed]

19. Magrinyà, N.; Terjung, N.; Loeffler, M.; Gibis, M.; Bou, R.; Weiss, J. Influence of fat addition on the antimicrobial activity of sodium lactate, lauric arginate and methylparaben in minced meat. Interl. J. Food Microbiol. 2015, 215, 86-94. [CrossRef] [PubMed]

20. Siripatrawan, U.; Harte, B.R. Physical properties and antioxidant activity of an active film from chitosan incorporated with green tea extract. Food Hydrocoll. 2010, 24, 770-775. [CrossRef]

21. Eagan, J.M.; Xu, J.; Di Girolamo, R.; Thurber, C.M.; Macosko, C.W.; LaPointe, A.M.; Bates, F.S.; Coates, G.W. Combining polyethylene and polypropylene: Enhanced performance with PE/iPP multiblock polymers. Science 2017, 355, 814-816. [CrossRef]

22. Krepker, M.; Prinz-Setter, O.; Shemesh, R.; Vaxman, A.; Alperstein, D.; Segal, E. Antimicrobial carvacrol-containing polypropylene films: Composition, structure and function. Polymers 2018, 10, 79. [CrossRef]

23. Polat, S.; Fenercioglu, H.; Turhan, E.U.; Guclu, M. Effects of nanoparticle ratio on structural, migration properties of polypropylene films and preservation quality of lemon juice. J. Food Process. Preserv. 2018, 42, e13541. [CrossRef]

24. Wang, Z.; Wang, D.; Fang, Y.; Shen, J. Preparation and properties of antistatic polyethylene film coated polypropylene non-woven fabrics. Fibers Polym. 2018, 19, 934-940. [CrossRef]

25. Llana-Ruiz-Cabello, M.; Pichardo, S.; Bermúdez, J.; Baños, A.; Núñez, C.; Guillamón, E.; Aucejo, S.; Cameán, A. Development of PLA films containing oregano essential oil (Origanum vulgare L.virens) intended for use in food packaging. Food Addit. Contam. Part A 2016, 33, 1374-1386. [CrossRef] [PubMed]

26. ASTM. Standard Test Method for Determining the Activity of Incorporated Antimicrobial Agent(s) in Polymeric or Hydrophobic Materials; E 2180-01; ASTM: West Conshohocken, PA, USA, 2002.

27. Burt, S.; Reinders, R. Antibacterial activity of selected plant essential oils against Escherichia coli O157:H7. Lett. Appl. Microbiol. 2003, 36, 162-167. [CrossRef] [PubMed]

28. Sienkiewicz, M.; Łysakowska, M.; Pastuszka, M.; Bienias, W.; Kowalczyk, E. The potential of use basil and rosemary essential oils as effective antibacterial agents. Molecules 2013, 18, 9334-9351. [CrossRef] [PubMed] 
29. Nemes, D.; Kovács, R.; Nagy, F.; Mező, M.; Poczok, N.Z.; Ujhelyi, P.Á.; Fehér, P.; Fenyvesi, F.; Váradi, J.; Vecsernyés, M.; et al. Interaction between different pharmaceutical excipients in liquid dosage forms-assessment of cytotoxicity and antimicrobial activity. Molecules 2018, 23, 1827. [CrossRef]

30. Bazzaz, B.S.F.; Sarabandi, S.; Khameneh, B.; Hosseinzadeh, H. Effect of Catechins, green tea extract and methylxanthines in combination with gentamicin against staphylococcus aureus and pseudomonas aeruginosa-combination therapy against resistant bacteria. J. Pharmacopunct. 2016, 19, 312-318. [CrossRef] [PubMed]

31. Cordeiro, A.M.T.M.; Medeiros, M.L.; Santos, N.A.; Soledade, L.E.B.; Pontes, L.F.B.L.; Souza, A.L.; Queiroz, N. Rosemary (Rosmarinus officinalis L.) extract. Thermal study and evaluation of the antioxidant effect on vegetable oils. J. Therm. Anal. Calorim. 2012, 113, 889-895. [CrossRef]

32. Liebert, M.A. Final report on the safety assessment of methylparaben, ethylparaben, propylparaben and butylparaben. J. Am. Coll. Toxicol. 1984, 3, 147-209.

33. Keawchaoon, L.; Yoksan, R. Preparation, characterization and in vitro release study of carvacrol-loaded chitosan nanoparticles. Colloid. Surf. B Biointerf. 2011, 84, 163-171. [CrossRef] [PubMed]

34. Ramos, M.; Beltran, A.; Valdes, A.; Peltzer, M.A.; Jimenez, A.; Zaikov, M.C.G.A.G.E. Carvacrol and thymol for fresh food packaging. J. Bioequivalence Bioavailab. 2013, 5. [CrossRef]

35. Yang, B.; Bai, Y.; Cao, Y. Effects of inorganic nano-particles on plasticizers migration of flexible PVC. J. Appl. Polym. Sci. 2013, 115, 2178-2182. [CrossRef]

36. Li, X.; He, Y.; Huang, C.; Zhu, J.; Lin, A.H.-M.; Chen, L.; Li, L. Inhibition of plasticizer migration from packaging to foods during microwave heating by controlling the esterified starch film structure. Food Control 2016, 66, 130-136. [CrossRef]

37. Huang, C.; Zhu, J.; Chen, L.; Li, L.; Li, X. Structural changes and plasticizer migration of starch-based food packaging material contacting with milk during microwave heating. Food Control 2014, 36, 55-62. [CrossRef]

38. Martyn, A.; Targoński, Z. Antymikrobiologiczne opakowania żywności. Żywność. Nauka. Technologia. Jakość. 2010, 5, 33-44.

39. Rodrigues, J.B.D.S.; de Carvalho, R.J.; de Souza, N.T.; Oliveira, K.D.S.; Franco, O.; Schaffner, D.; de Souza, E.L.; Magnani, M. Effects of oregano essential oil and carvacrol on biofilms of Staphylococcus aureus from food-contact surfaces. Food Control 2017, 73, 1237-1246. [CrossRef]

40. Szczepanski, S.; Lipski, A. Essential oils show specific inhibiting effects on bacterial biofilm formation. Food Control 2014, 36, 224-229. [CrossRef]

41. Llana-Ruiz-Cabello, M.; Pichardo, S.; Bermudez, J.M.; Baños, A.; Ariza, J.J.; Guillamón, E.; Aucejo, S.; Cameán, A.M. Characterisation and antimicrobial activity of active polypropylene films containing oregano essential oil and Allium extract to be used in packaging for meat products. Food Addit. Contam. Part A 2018, 35, 783-792. [CrossRef]

42. Ramos, M.; Beltrán, A.; Peltzer, M.A.; Valente, A.J.; Garrigós, M.D.C. Release and antioxidant activity of carvacrol and thymol from polypropylene active packaging films. LWT Food Sci. Tech. 2014, 58, 470-477. [CrossRef] 